\title{
Effect of COD:N ratio on biological nitrogen removal using full-scale step-feed in municipal wastewater treatment plants
}

\author{
Supaporn Phanwilai ${ }^{1}$, Pongsak Noophan ${ }^{1 *}$ (D), Chi-Wang Li ${ }^{2}$ and Kwang-Ho Choo 3,4
}

\begin{abstract}
This study investigated the effect of low and high chemical oxygen demand (COD): $\mathrm{N}$ ratios on biological nitrogen removal and microbial distributions in full-scale step-feed (SF) municipal wastewater treatment plants (WWTPs) in Thailand $\left(\mathrm{SF}_{1}\right)$ and Taiwan $\left(\mathrm{SF}_{2}\right)$. The SF, WWTP had a low COD:N (4:1) ratio, a long solids retention time (SRT) (> 60 d), and low dissolved oxygen (DO) conditions $\left(0.2 \mathrm{mg} \mathrm{L}^{-1}\right.$ in anoxic tank and $0.9 \mathrm{mg} \mathrm{L}^{-1}$ in aerobic tank). The total nitrogen (TN) removal efficiency was 48\%. The $\mathrm{SF}_{2}$ WWTP had a high COD:N (10:1) ratio, a short SRT (7 d), and high DO (0.6 $\mathrm{mg} \mathrm{L}^{-1}$ in anoxic tank and $1.8 \mathrm{mg} \mathrm{L}^{-1}$ in aerobic tank). The TN removal efficiency was $61 \%$. The nitrification and denitrification rates from these two plants were inadequate. Using a quantitative polymerase chain reaction ( $\mathrm{PPCR}$ ) technique, the populations of ammonium oxidizing bacteria (AOB) and ammonium oxidizing archaea were quantified. Measurement of ammonia monooxygenase $(a m o A)$ gene abundances identified these AOB:

Nitrosomonas sp., Nitrosospira sp., Nitrosoccus sp. and Zoogloea sp. Higher amounts of the archaeal-amoA gene were found with long SRT, lower DO and COD:N ratios. Abundance of Nitrobacter sp. was slightly higher than Nitrospira sp. at the $\mathrm{SF}_{1}$, while abundance of Nitrobacter sp. was two orders of magnitude greater than Nitrospira sp. at the $\mathrm{SF}_{2}$. More denitrifying bacteria were of the nirS-type than the nirk-type, especially at higher COD:N ratio. Most bacteria belong to the phyla Acidobacteria, Actinobacteria Bacteroidetes, Chloroflexi, Proteobacteria. The results from this work showed that insufficient carbon sources at the $\mathrm{SF}_{1}$ and high $\mathrm{DO}$ concentration in anoxic tank of $\mathrm{SF}_{2}$ adversely affected nitrogen removal efficiencies. In further research work, advanced techniques on the next generation sequencing with different variable regions should be recommended in full-scale WWTPs.
\end{abstract}

Keywords: Biological nitrogen removal, COD:N, Full-scale, Step-feed

\section{Introduction}

Increases in water pollution are usually related to growing urban populations. Efficient removal of nitrogen in wastewater treatment plants (WWTPs) is essential to avoid downstream eutrophication which adversely affects not only animal but also human health globally. Nitrogen is removed from wastewaters with physical methods (air stripping), chemical methods (ion exchange), biological treatment (nitrification and denitrification processes), and/

\footnotetext{
* Correspondence: fengpsn@ku.ac.th

'Department of Environmental Engineering, Faculty of Engineering, Kasetsart University, Bangkok 10900, Thailand

Full list of author information is available at the end of the article
}

or combinations of these. Biological treatment processes are dominant over all other physical and chemical methods and are attractive because of relative low costs [1].

The most popular domestic wastewater treatment system for large communities is activated sludge process with plug flow configuration. However, with some sitespecific conditions, existing processes or equipment and demand for high biological nitrogen removal efficiency, a modification of plug flow with step-feed is recommended. Dividing a reactor tank into anoxic and aerobic zones and/or using step-feed configuration are commonly recommended for improving nitrogen removal [2]. However, not all step-feed configurations require

(c) The Author(s). 2020 Open Access This article is licensed under a Creative Commons Attribution 4.0 International License, which permits use, sharing, adaptation, distribution and reproduction in any medium or format, as long as you give appropriate credit to the original author(s) and the source, provide a link to the Creative Commons licence, and indicate if changes were made. The images or other third party material in this article are included in the article's Creative Commons licence, unless indicated otherwise in a credit line to the material. If material is not included in the article's Creative Commons licence and your intended use is not permitted by statutory regulation or exceeds the permitted use, you will need to obtain permission directly from the copyright holder. To view a copy of this licence, visit http://creativecommons.org/licenses/by/4.0/. 
pre-anoxic process. The step-feed process has many advantages over conventional activated sludge processes, including more uniform distribution of oxygen demand, superior ability to handle peak wet-weather flows, and flexible operation. Step-feed systems can often achieve treatment objectives with smaller bioreactor volumes [3], and the process will often achieve low effluent total inorganic nitrogen concentrations [4].

The key factors affecting full-scale step-feed WWTPs are dissolved oxygen (DO), solids retention time (SRT), and hydraulic retention time (HRT). Operation with internal recycle reduced total nitrogen (TN) concentrations between 5 and $8 \mathrm{mg} \mathrm{L}^{-1}$ with SRT between 3 and $15 \mathrm{~d}$, total HRT $3-5 \mathrm{~h}$, anoxic zone time $0.5-1.5 \mathrm{~h}$, aerobic zone time $2.5-3.5 \mathrm{~h}$, aerobic tank DO $2-3 \mathrm{mg} \mathrm{L}^{-1}$ and anoxic tank DO $\leq 0.2 \mathrm{mg} \mathrm{L}^{-1}$ [5]. Wang and Chen [6] reported TN removal efficiency of $>64 \%$ in a fullscale step-feed system operated at DO of $<0.25 \mathrm{mg} \mathrm{L}^{-1}$ in anoxic tank and $2 \mathrm{mg} \mathrm{L}^{-1}$ in aerobic tank with temperature between $11.9-23.3^{\circ} \mathrm{C}$. Moreover, in a pilotscale step-feed system investigated by Ge et al. [7], TN removal efficiencies varied from 75 to $86 \%$ with different SRTs at $10-15 \mathrm{~d}(75 \%), 10-12 \mathrm{~d}(82 \%)$ and $8-10 \mathrm{~d}$ (86\%) under DO concentrations of $1.2-2.0 \mathrm{mg} \mathrm{L}^{-1}$ in aerobic zones.

Information on TN removal for full-scale step-feed municipal WWTP specifically for low and high chemical oxygen demand (COD): $\mathrm{N}$ ratios and various DO concentrations is rare in the literature. For this reason, our work was focused on two full-scale step-feed WWTPs in Bangkok, Thailand and Taipei, Taiwan. These two fullscale WWTPs with similar configurations were selected because of low and high COD:N ratios in influent. The definitions for high and low COD:N ratios of wastewaters are $>4.3: 1$ and $\leq 4.3: 1$, respectively. The study compared the efficiencies of nitrogen removal from these step-feed WWTPs, and different observations due to design parameters and operating conditions were explained. In addition, the abundance of microbial communities in these full-scale WWTPs were investigated and discussed. The results from this work could be applied to step-feed WWTPs in either country to solve carbon limitation when treating low COD:N wastewater and/or reduce aeration energy by using low-DO processes for improving biological nitrogen removal efficiencies.

\section{Materials and methods \\ Wastewater treatment systems}

Two underground full-scale municipal step-feed WWTPs were selected from the downtown area of two capital cities, Bangkok, Thailand, $\left(\mathrm{SF}_{1}\right)$ and Taipei, Taiwan, $\left(\mathrm{SF}_{2}\right)$. All wastewaters samples were collected and analyzed over an entire year (2018-2019). Both plants were designed for removal of both organic matter and nitrogen with reaction tanks consisting of anoxicaerobic zones. The $\mathrm{SF}_{1}$ (see Fig. 1a) had four feed points to four anoxic and four aerobic tanks. However, due to low flow conditions into the $\mathrm{SF}_{1}$ system, only two feed points were operated and rotated with another two feed points. The $\mathrm{SF}_{2}$ (see Fig. 1b) had three feed points to three anoxic tanks and three large aeration tanks (each large aeration tank was divided to four small aeration tanks) due to high flow of the system. These two WWTPs were built underground because of land limitations in these dense capital cities. The above ground areas of these two plants were used as recreation and education centers.

\section{Analytical methods}

Influent and effluent samples from each full-scale stepfeed WWTP in this work were collected monthly during 2018-2019. Characteristics of these samples were measured by using the method described in Standard Methods for the Examination of Water and Wastewater (2005). Mixed liquor suspended solids (MLSS) and mixed liquor volatile suspended solids (MLVSS) from each reactor tank were also analyzed by following the method described in Standard Methods. Temperature and $\mathrm{pH}$ were immediately measured in the field.

\section{Nitrification and denitrification rates}

To calculate the nitrification rates with various COD:N ratios, the concentration of ammonium-nitrogen $\left(\mathrm{NH}_{4}{ }^{+}{ }_{-}\right.$ $\mathrm{N}$ ) in influent and effluent was determined. The nitrification rate was defined based on the $\mathrm{NH}_{4}{ }^{+}-\mathrm{N}$ removal as shown in Eq. (1) [8],

$$
\begin{aligned}
\gamma_{\text {nitrification }}= & \mathrm{Q}_{\text {in }} \\
& \times \frac{\mathrm{NH}_{4}^{+}-\mathrm{N}_{\text {influent }}-\mathrm{NH}_{4}^{+}-\mathrm{N}_{\text {effluent }}}{\mathrm{V}_{\text {reactor }} \times \mathrm{VSS}_{\text {nitrifying in reactor }}},
\end{aligned}
$$

where $\gamma_{\text {nitrification }}$ is the nitrification rate $\left(\mathrm{d}^{-1}\right), \mathrm{Q}_{\text {in }}$ is flow rate $\left(\mathrm{m}^{3} \mathrm{~d}^{-1}\right), V_{\text {reactors }}$ is volume of reactors $\left(\mathrm{m}^{3}\right)$,

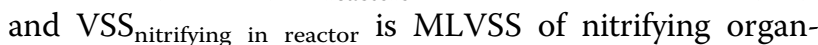
isms in reactor $\left(\mathrm{mg} \mathrm{L}^{-1}\right)$.

The nitrifying organisms in the reactor is calculated based on MLVSS using Eqs. (2) and (3),

$$
\begin{gathered}
\text { MLVSS }_{\text {nitrifying in reactor }}=\mathrm{f}_{\mathrm{N}} \times \mathrm{VSS}_{\text {reactors }}, \\
\mathrm{f}_{\mathrm{N}}=\frac{0.16 \times\left(\mathrm{NH}_{4}^{+}-\mathrm{N}_{\text {influent }}-\mathrm{NH}_{4}^{+}-\mathrm{N}_{\text {effluent }}\right)}{0.6 \times\left(\mathrm{BOD}_{\text {influent }}-\mathrm{BOD}_{\text {effluent }}\right)+0.16 \times\left(\mathrm{NH}_{4}^{+}-\mathrm{N}_{\text {influent }}-\mathrm{NH}_{4}^{+}-\mathrm{N}_{\text {effluent }}\right)},
\end{gathered}
$$

where $f_{\mathrm{N}}$ is the fraction of nitrifying organisms presenting in the mixed liquor of a step-feed system. This fraction of nitrifying organisms can be estimated using Eq. (3). $\mathrm{BOD}_{\text {influent }}$ and $\mathrm{BOD}_{\text {effluent }}$ are the 


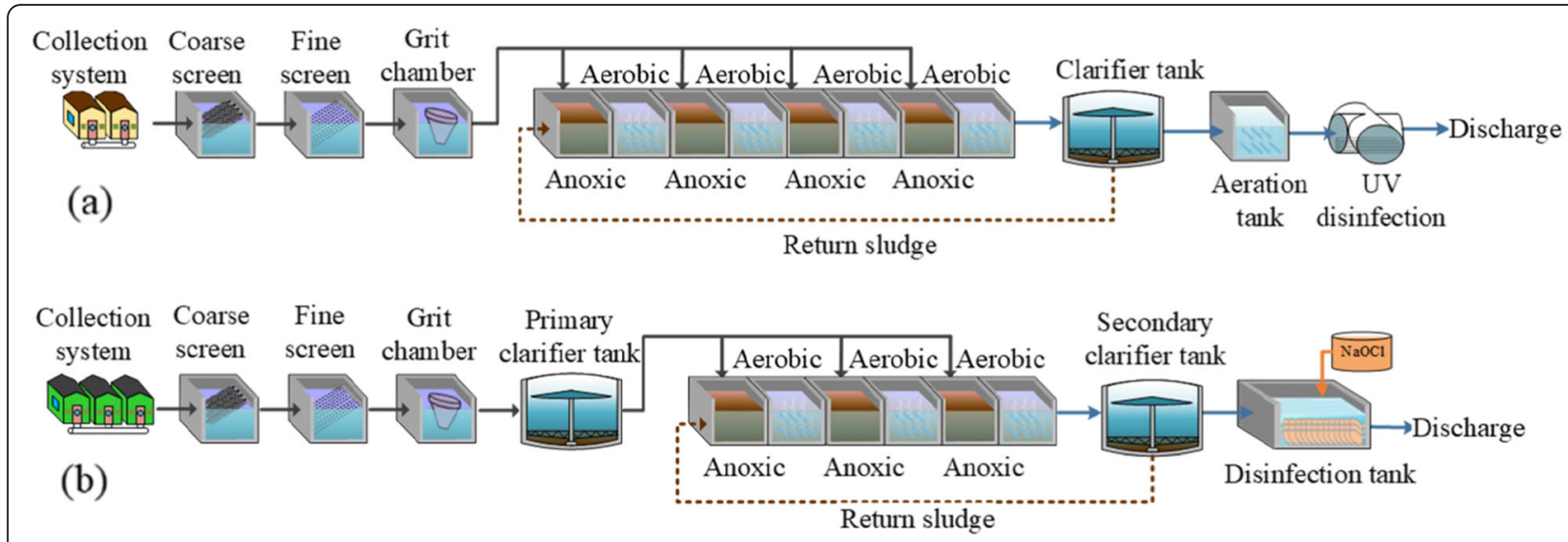

Fig. 1 Diagrams of the full-scale step feed systems in a Thailand and $\mathbf{b}$ Taiwan

concentrations of biochemical oxygen demand in influents and effluents $\left(\mathrm{mg} \mathrm{L}^{-1}\right)$, respectively. The denitrification rate was defined as Eq. (4),

$$
\gamma_{\text {denitrification }}=\frac{\mathrm{Q}_{\text {in }} \times\left[\left(\mathrm{TKN}_{\text {influent }}-\mathrm{NH}_{4}^{+}-\mathrm{N}_{\text {effluent }}\right)-\left(\mathrm{NO}_{3}^{-}-\mathrm{N}_{\text {effluent }}\right)\right]}{\left(\mathrm{V}_{\text {reactors }}\right) \times\left(\mathrm{VSS}_{\text {reactors }}\right)},
$$

where $\gamma_{\text {denitrification }}$ is the denitrification rate $\left(\mathrm{d}^{-1}\right)$ and $\left[\mathrm{TKN}_{\text {influent }}-\left(\mathrm{NH}_{4}{ }^{+}-\mathrm{N}\right)_{\text {influent }}\right]$ can be substituted with organic nitrogen in the influent. The TN removal (\%) was calculated using Eq. (5).

$$
\begin{aligned}
\mathrm{TN}_{\text {removal }}(\%)= & \frac{\mathrm{NH}_{4}^{+}-\mathrm{N}_{\text {influent }}-\mathrm{NH}_{4}^{+}-\mathrm{N}_{\text {effluent }}}{\mathrm{NH}_{4}^{+}-\mathrm{N}_{\text {influent }}} \\
& \times 100
\end{aligned}
$$

\section{Microbial communities analysis}

Sludge samples from $\mathrm{SF}_{1}$ and $\mathrm{SF}_{2}$ and were taken from both anoxic and aerobic tanks for the analysis of microbial communities. The nitrifying bacterial communities were identified through analysis of ammonia monooxygenase $(a m o A)$ gene abundances of ammonium oxidizing bacteria $(\mathrm{AOB})$ and ammonium oxidizing archaea (AOA). The 16S rDNA target gene of Nitrospira (NSR) and Nitrobacter (Nitro) was used to determine nitrite oxidizing bacteria (NOB) abundance. The functional targeted gene of nirK and nirS genes were used as molecular markers for denitrifying bacterial (DNB) abundances.

\section{DNA extraction and polymerase chain reaction (PCR) amplification}

$1 \mathrm{~mL}$ of the samples were taken for DNA extraction following the manufacturer's method using FavorPrep ${ }^{\mathrm{Tm}}$ soil DNA isolation mini kit (Favogen ${ }^{\circ}$ Biotech Corp, Taiwan). The PCR protocol and oligonucleotide primers for quantitative PCR (qPCR) and denaturing gradient gel electrophoresis are shown in Table S1 in Supplemental Materials.

\section{qPCR of functional and 16S rDNA genes}

The qPCR mixture contained $10 \mu \mathrm{L}$ of SYBR Green by Luna $^{\circ}$ Universal qPCR Master Mix (New England Biolabs, MA, USA), $10 \mathrm{pmol}$ of each primer, $1 \mu \mathrm{L}$ of DNA template $\left(\sim 10-20 \mathrm{ng} \mu \mathrm{L}^{-1}\right)$ and nuclease-free water up $20 \mu \mathrm{L}$ per reaction. Each sample and the standard series $\left(10^{0}-10^{8}\right)$ were performed in triplicate on CFX96 Touch $^{\text {tw }}$ Real-Time PCR detection systems (Bio-Rad Laboratories, CA, USA) and the results were active based on the correlation coefficient of the standard curve $\left(R^{2}=0.995\right)$.

\section{Denaturing gradient gel electrophoresis (DGGE) fingerprints}

The PCR mixture contained 10X Ex Taq ${ }^{\mathrm{mi}}$ buffer, 5 units $\mu \mathrm{L}^{-1}$ TaKaRa Ex Taq $q^{\mathrm{ms}}, 2.5 \mathrm{mM}$ dNTP Mixture, 10 pmol of each primer, $1 \mu \mathrm{L}$ of DNA template $(\sim 10-20$ ng $\left.\mu \mathrm{L}^{-1}\right)$ and nuclease-free water up to $25 \mu \mathrm{L}$ per reaction. Each sample was completed on T100 ${ }^{\text {ts }}$ Thermal cycler (Bio-Rad Laboratories, CA and USA). $15 \mu \mathrm{L}$ of each PCR product was loaded into individual lanes of a DGGE gel of $8 \%(\mathrm{~W} / \mathrm{V})$ acrylamide gel with $35-60 \%$ (EUB) and 35-50\% (AOB), and 6\% (W/V) acrylamide gel with $20-50 \%$ (AOA) denaturing gradients. Electrophoresis was performed for $16 \mathrm{~h}$ at $58^{\circ} \mathrm{C}$ with a constant voltage at $80 \mathrm{~V}$ in $1 \mathrm{X}$ TAE buffer. Each DGGE band was excised with a scalpel, DNA fragment was eluted from the band by milli-Q water overnight in a refrigerator, followed by PCR with the same primer without attached CG-clamp. Representative sequences were aligned against the National Center for Biotechnology Information database using Basic Local Alignment Search Tool. In this work, nirK and nirS genes were used because they are typically contained in denitrifying bacteria, but are structurally different from nitrite reductase 
(distinguish the copper-dependent nitrite reductase and cytochrome $c d_{1}$-containing nitrite reductase).

\section{Results and discussion \\ Key operating conditions of the full-scale step-feed WWTPs and wastewater quality}

The key average operating parameters of the $\mathrm{SF}_{1}$ and $\mathrm{SF}_{2}$ WWTPs are shown in Table 1. The characteristics of influent and effluent of each SF are shown in Table 2. The BOD:TN and COD:N ratios of $\mathrm{SF}_{1}$ were $2: 1$ and 4:1, respectively. The BOD:TN and COD:N ratios of $\mathrm{SF}_{2}$ were 4.6:1 and 10:1, respectively. The wastewater treatment loading rate, BOD:TN and COD:N ratios of $\mathrm{SF}_{1}$ were significantly lower than those in $\mathrm{SF}_{2}$. Both $\mathrm{SF}_{1}$ and $\mathrm{SF}_{2}$ were able to remove SS, COD, and BOD well, but not nitrogen and phosphorus. At $\mathrm{SF}_{1}$, there was not enough carbon source (low BOD in the influent) for denitrifying bacteria as electron donor. For this reason, this insufficient carbon source would affect on denitrification process.

The process performances on $\mathrm{COD}, \mathrm{NH}_{4}{ }^{+}-\mathrm{N}, \mathrm{NO}_{2}{ }^{-}$ $\mathrm{N}$, and $\mathrm{NO}_{3}{ }^{-}-\mathrm{N}$ concentrations profile of $\mathrm{SF}_{1}$ and $\mathrm{SF}_{2}$ WWTPs are shown in Fig. 2. Although BOD:N and COD:N ratios of $\mathrm{SF}_{1}$ were significantly lower than $\mathrm{SF}_{2}$, the $\mathrm{NH}_{4}{ }^{+}-\mathrm{N}$ removal efficiency of $\mathrm{SF}_{1}(>88 \%)$ was higher than that of $\mathrm{SF}_{2}(59 \%)$. Average temperature of wastewater at $\mathrm{SF}_{1}$ was higher than average temperature of wastewater at $\mathrm{SF}_{2}$ (Table 2). Higher average temperature and longer SRT for $\mathrm{SF}_{1}$ could be significant factors promoting $\mathrm{AOB}$ activities. Although the $\mathrm{DO}$ concentration in the aerobic tank of $\mathrm{SF}_{1}$ was quite low, the $\mathrm{DO}$ was sufficient for adequate nitrification. It is also noted that the concentration of nitrifier communities at $\mathrm{SF}_{1}$ was significantly higher than that for $\mathrm{SF}_{2}$ (see subsequent Section microbial communities $\mathrm{AOB}$ and $\mathrm{NOB}$ populations and communities).

\section{Nitrification and denitrification rates}

Overall biological nitrogen removal in $\mathrm{SF}_{1}$ and $\mathrm{SF}_{2}$ was determined by calculating nitrification and denitrification rates in the aerobic and anoxic tanks. These two

Table 1 Key average parameters of two full-scale step feed (SF) WWTPS

\begin{tabular}{lll}
\hline Parameter & $\mathbf{S F}_{\mathbf{1}}$ & $\mathbf{S F}_{\mathbf{2}}$ \\
\hline Avg. flow rate $\left(\mathrm{m}^{3} \mathrm{~d}^{-1}\right)$ & $84,000 \pm 5000$ & $433,820 \pm 8000$ \\
SRT (d) & $>60$ & $7 \pm 1$ \\
HRT (h) & 4.1 (avg.) & 4.5 (avg.) \\
Anoxic & $1.8 \pm 0.5$ & $0.7 \pm 0.5$ \\
Aerobic & $2.3 \pm 1.5$ & $3.8 \pm 1.2$ \\
DO $\left(\mathrm{mg} \mathrm{L}^{-1}\right)$ & & \\
$\quad$ Anoxic & $0.2 \pm 0.3$ & $0.6 \pm 0.5$ \\
Aerobic & $0.9 \pm 0.5$ & $1.8 \pm 0.5$ \\
\hline
\end{tabular}

rates should not be the same value [9]. In this work the nitrification and denitrification rates of $\mathrm{SF}_{1}$ and $\mathrm{SF}_{2}$ were significantly different (Table 3 ). There are several possible explanations for this inequality. First, Thai sewage piping combines wastewater and rainwater that occurs all seasons, diluting the Thai influent BOD and SS to very low levels ( $<50 \mathrm{mg} \mathrm{L}^{-1}$ and $<90 \mathrm{mg} \mathrm{L}^{-1}$, respectively) [10]. Second, the MLVSS:MLSS ratio of $\mathrm{SF}_{1}$ was only $0.45-0.55$ compared with that of $\mathrm{SF}_{2}(0.8-0.82)$ due to longer SRT in both anoxic and aerobic tanks in $\mathrm{SF}_{1}$. For this reason, when MLVSS is used to calculate biomass, inaccurate higher estimations of microorganisms would result. The significant difference of MLVSS:MLSS ratio between $\mathrm{SF}_{1}$ and $\mathrm{SF}_{2}$ might also be due to the absence of primary clarifier in SF1. The main purpose of a primary clarifier is to remove solids and particulates. Third, other factors affecting the growth of nitrifiers and denitrifiers would include DO concentration, SRT duration and temperature. Especially important was maintenance of appropriate DO concentration $\left(<0.2 \mathrm{mg} \mathrm{L}^{-1}\right)$ in the anoxic phase [6].

In this study, it was shown that the longer SRT ( $>60 \mathrm{~d}$ ) of $\mathrm{SF}_{1}$ promoted $\mathrm{TN}$ removal efficiency (48\%) although the COD:N at this plant was quite low. Davies et al. [11] reported that longer SRTs improved nitrification and denitrification, resulting in high $\mathrm{TN}$ removal efficiency. At $\mathrm{SF}_{2}$, the operation was normal with sufficient carbon presence (high COD:N ratio) but TN removal efficiency (only 61\%) was not much better than that of $\mathrm{SF}_{1}$. Moreover, the nitrification and denitrification rates were only 1.23 and $0.12 \mathrm{~g} \mathrm{NH}_{4}{ }^{+}-\mathrm{N} \mathrm{g}^{-1}$ $\mathrm{VSS} \mathrm{d}^{-1}$, respectively. The main reason for the low nitrogen removal efficiency and differing microbial processes was excessive DO in anoxic tank $\left(0.6 \mathrm{mg} \mathrm{L}^{-1}\right)$. Other investigators $[9,12,13]$ have stated that high DO concentration enhances nitrification rates in aerobic tank while not increasing denitrification rates in anoxic tank. Maintaining lower DO concentrations $\left(<1.0 \mathrm{mg} \mathrm{L}^{-1}\right)$ throughout an entire year in aerobic tank adversely affected the nitrification process (TN removal efficiency only 55\%). Meng et al. [14] reported that TN removal was increased to $78 \%$ by increasing DO concentrations to $>1.0 \mathrm{mg} \mathrm{L}^{-1}$. Wang and Chen [6] demonstrated that a simultaneous nitrification-denitrification (anoxic-aerobic) process could result in TN removal efficiency of $57 \%$. They also suggested that DO concentration in anoxic tank should be $<0.25 \mathrm{mg} \mathrm{L}^{-1}$ and aeration should be reduced when the DO concentration exceeds $2 \mathrm{mg} \mathrm{L}^{-1}$ in the aerobic tank. This current study showed that at both $\mathrm{SF}_{1}$ and $\mathrm{SF}_{2}$, DO levels between 0.2 and $0.6 \mathrm{mg} \mathrm{L}^{-1}$ in anoxic tank could be postulated to impact on the denitrification rate.

\section{Microbial communities by using qPCR and DGGE technique} $A O B$ and archaea $(A O A)$ populations and communities The different COD:N ratios at $\mathrm{SF}_{1}$ and $\mathrm{SF}_{2}$ affected the sizes of archaeal-amoA (AOA) and bacterial-amoA 
Table 2 Characteristics of wastewaters from each full-scale step feed WWTP

\begin{tabular}{|c|c|c|c|c|c|c|}
\hline \multirow[t]{2}{*}{ Parameter } & \multicolumn{3}{|l|}{$\mathrm{SF}_{1}$} & \multicolumn{3}{|l|}{$\mathrm{SF}_{2}$} \\
\hline & Influent & Effluent & \% Removal & Influent & Effluent & \% Removal \\
\hline Temp $\left({ }^{\circ} \mathrm{C}\right)$ & $27.1 \pm 0.1$ & $27.4 \pm 0.2$ & - & $25.2 \pm 2.0$ & $25.1 \pm 2.5$ & - \\
\hline $\mathrm{pH}$ & $7.4-7.6$ & $7.2-7.4$ & - & $7.0-7.2$ & $6.9-7.1$ & - \\
\hline $\mathrm{SS}\left(\mathrm{mg} \mathrm{L}^{-1}\right)$ & $36 \pm 2$ & $6 \pm 1$ & $83 \pm 2$ & $127 \pm 16$ & $14 \pm 2$ & $88 \pm 0.5$ \\
\hline $\mathrm{BOD}\left(\mathrm{mg} \mathrm{L}^{-1}\right)$ & $35 \pm 2$ & $6 \pm 1$ & $83 \pm 2$ & $126 \pm 21$ & $10 \pm 2$ & $91 \pm 0.1$ \\
\hline $\operatorname{COD}\left(\mathrm{mg} \mathrm{L}^{-1}\right)$ & $73 \pm 5$ & $18 \pm 2$ & $75 \pm 1$ & $275 \pm 24$ & $30 \pm 2$ & $89 \pm 0.2$ \\
\hline $\mathrm{NH}_{4}^{+}\left(\mathrm{mg} \mathrm{L}^{-1}\right)$ & $13.3 \pm 0.2$ & $2.3 \pm 0.4$ & $83 \pm 6$ & $21 \pm 2.5$ & $8.6 \pm 1.4$ & $59 \pm 5$ \\
\hline $\mathrm{NO}_{3}^{-}\left(\mathrm{mg} \mathrm{L}^{-1}\right)$ & $0.4 \pm 0.1$ & $5.2 \pm 0.5$ & - & $0.20 \pm 0.08$ & $0.5 \pm 0.04$ & - \\
\hline $\mathrm{NO}_{2}^{-}\left(\mathrm{mg} \mathrm{L}^{-1}\right)$ & $0.1 \pm 0.05$ & $0.02 \pm 0.01$ & $78 \pm 11$ & $0.04 \pm 0.02$ & $0.02 \pm 0.01$ & $50 \pm 1$ \\
\hline Organic-N (mg L $\left.{ }^{-1}\right)$ & $4.4 \pm 0.1$ & $1.9 \pm 0.16$ & $57 \pm 3$ & $4.2 \pm 1.71$ & $1.5 \pm 0.9$ & $67 \pm 8$ \\
\hline TKN $\left(\mathrm{mg} \mathrm{L}^{-1}\right)$ & $17.7 \pm 0.3$ & $4.2 \pm 0.56$ & $76 \pm 3$ & $25.2 \pm 4.2$ & $10.1 \pm 1.0$ & $60 \pm 3$ \\
\hline $\mathrm{TN}\left(\mathrm{mg} \mathrm{L}^{-1}\right)$ & $18.2 \pm 0.4$ & $9.4 \pm 2.1$ & $48 \pm 10$ & $25.4 \pm 4.3$ & $10.6 \pm 2.4$ & $59 \pm 2$ \\
\hline $\mathrm{TP}\left(\mathrm{mg} \mathrm{L}^{-1}\right)$ & $3.0 \pm 0.2$ & $1.9 \pm 0.1$ & $37 \pm 4$ & $2.9 \pm 0.8$ & $1.5 \pm 0.7$ & $48 \pm 12$ \\
\hline
\end{tabular}

Remark: All data values are averages \pm S.D., $n=12$ samples

(AOB) populations. Figure 3 shows that a large amount of AOA $\left(1.0 \times 10^{5}\right.$ copies $\mathrm{mL}^{-1}$ sludge $)$ was found with the low COD:N ratio of $\mathrm{SF}_{1}$. However, very low amounts of AOA $\left(1.0 \times 10^{0}\right.$ copies $\mathrm{mL}^{-1}$ sludge $)$ were found with the higher COD:N ratio of $\mathrm{SF}_{2}$. The very low amount of AOA found in $\mathrm{SF}_{2}$, but not in $\mathrm{SF}_{1}$, is due to the high DO concentration $\left(>1.8 \mathrm{mg} \mathrm{L}^{-1}\right)$ maintained in the aerobic tank. The quantitative results for AOA and $\mathrm{AOB}$ in this study were similar to that of Kayee et al. [15] who found an abundance of AOA in municipal full-scale anoxic and aerobic tanks at the Bangkok WWTP, which had low COD:N ratio (4.3:1), still higher than the COD: $\mathrm{N}$ ratio of $\mathrm{SF}_{1}$ in this work. In Kayee's work, it was shown that the low DO concentration was maintained in
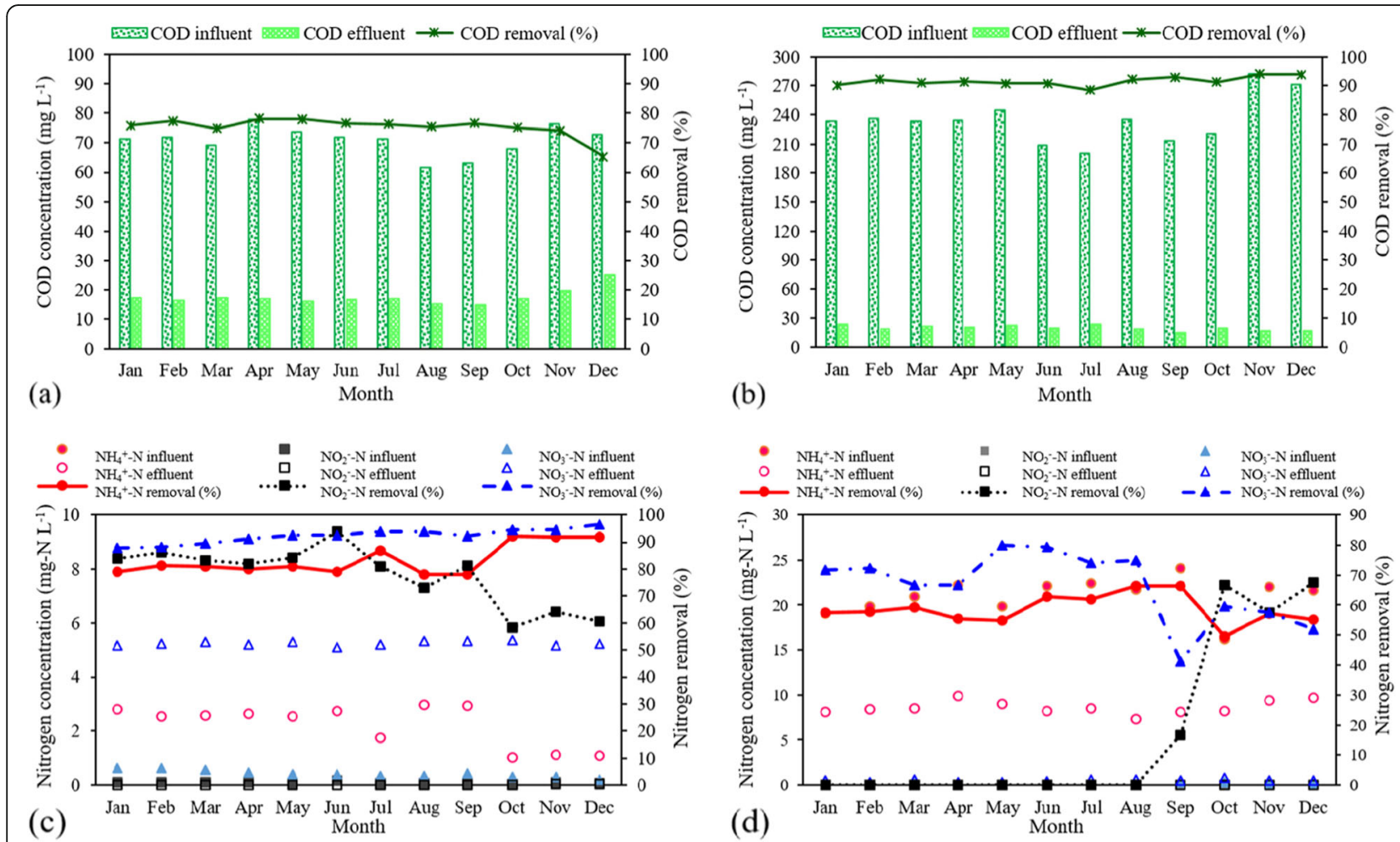

Fig. 2 Process performances on COD concentrations profile from a $\mathrm{SF}_{1}$ and from $\mathbf{b} \mathrm{SF}_{2}$, and nitrogen $\left(\mathrm{NH}_{4}{ }^{+}-\mathrm{N}_{1} \mathrm{NO}_{2}{ }^{-}-\mathrm{N}_{1}\right.$ and $\left.\mathrm{NO}_{3}{ }^{-}-\mathrm{N}\right)$ concentrations profile from $\mathbf{c} \mathrm{SF}_{1}$ and from $\mathbf{d} \mathrm{SF}_{2}$ 
Table 3 Nitrification and denitrification rates and TN removal efficiencies of both $\mathrm{SF}_{1}$ and $\mathrm{SF}_{2}$

\begin{tabular}{|c|c|c|c|c|}
\hline WWTP & Influent COD: $\mathrm{N}$ ratio $\left(\mathrm{g}\right.$ COD $\left.\mathrm{g}^{-1} \mathrm{~N}\right)$ & $\begin{array}{l}\text { Nitrification rate } \\
\left(\mathrm{g} \mathrm{NH}_{4}{ }^{+}-\mathrm{N} \mathrm{g}^{-1} \mathrm{VSS} \mathrm{d}^{-1}\right)\end{array}$ & $\begin{array}{l}\text { Denitrification rate } \\
\left(\mathrm{g} \mathrm{NO}_{3}^{-}-\mathrm{N} \mathrm{g}^{-1} \mathrm{VSS} \mathrm{d}^{-1}\right)\end{array}$ & TN removal (\%) \\
\hline$\overline{S F_{1}}$ & $4: 1$ & $0.55 \pm 0.02$ & $0.047 \pm 0.003$ & $48 \pm 10$ \\
\hline $\mathrm{SF}_{2}$ & $10: 1$ & $1.23 \pm 0.15$ & $0.12 \pm 0.03$ & $59 \pm 2$ \\
\hline
\end{tabular}

aerobic tank of these WWTPs. Low DO concentration and longer SRT in full-scale WWTPs promoted large populations of AOA [16-18]. Gao et al. [16] found that a high ratio of COD:N (10.7:1) in full-scale activated sludge plants in Beijing, China, along with low DO concentration $(0.5 \mathrm{mg}$ $\mathrm{L}^{-1}$ ) in the aerobic tank, led to large populations of AOA. It is noted that the relatively high temperature of wastewater in this work (only for $\mathrm{SF}_{1}$ ) could be a contributing factor for the abundance of AOA and AOB populations. Several studies reported the effects of warm climate on AOA and nitrifying community. For example, Limpiyakorn et al. [17] found high AOA and other nitrifying communities in domestic and industrial WWTPs in Thailand. Sinthusith et al. [18] reported that long SRT with high temperature $\left(30^{\circ} \mathrm{C}\right)$ and $\mathrm{pH}>7$ at the WWTP in Thailand was associated with the dominance of $\mathrm{AOA}$ amo $A$ genes over $\mathrm{AOB}$ amo $A$ genes.

As indicated in Fig. 4, $\mathrm{AOB}$ species in the $\mathrm{SF}_{1}$ were the same as in $\mathrm{SF}_{2}$. AOB species included Nitrosomonas europaea, Nitrosomonas halophile, Nitrosospira multiformis, Nitrosospira tenuis and Zoogloea caeni via $16 \mathrm{~S}$ rRNA of CTO primer pairs and Nitrosoccus halophilus via $16 \mathrm{~S}$ rRNA of EUB primer pairs (see Table S2). Moreover, AOB communities present in this study were similar to those found by Shen et al. [19], who investigated the microbial community in a full-scale domestic
WWTP (anoxic/oxic process). The main AOA communities at $\mathrm{SF}_{1}$ were Crenarchaeotal sp. and uncultured Thaumarchaeote. Thaumarchaeota are autotrophic and capable of performing the oxidation of $\mathrm{NH}_{4}{ }^{+}$to $\mathrm{NO}_{2}{ }^{-}$ [20, 21]. Generally, Crenarchaeotes have been found in extreme environments, such as low oxygen concentrations in aquatic systems, hot springs, and full-scale anaerobic digester systems [22-24]. For full scale WWTP applications, it would be advantageous to maintain conditions which support $\mathrm{AOA}$ and $\mathrm{AOB}$ communities to improve biological nitrogen removal.

\section{NOB populations and communities}

In the second step of nitrification, Nitrobacter sp. and Nitrospira sp. are classically acknowledged as the most relevant NOB group in WWTPs. In Fig. 3, the copies number of Nitrospira via NSR gene were found $1.0 \times 10^{4}$ copies $\mathrm{mL}^{-1}$ sludge at $\mathrm{SF}_{1}$ (low COD:N ratio), but they were present at less than $1.0 \times 10^{2}$ copies $\mathrm{mL}^{-1}$ sludge at $\mathrm{SF}_{2}$ (high COD:N ratio). For Nitrobacter via Nitro gene $1.0 \times 10^{5}$ copies $\mathrm{mL}^{-1}$ sludge) no significant difference was found between $\mathrm{SF}_{1}$ and $\mathrm{SF}_{2}$. Yu et al. [25] reported on fluorescence in situ hybridization (FISH) technique results in their submerged membrane bioreactors under two SRTs (30 and 90 d). The fast-growing Nitrobacter

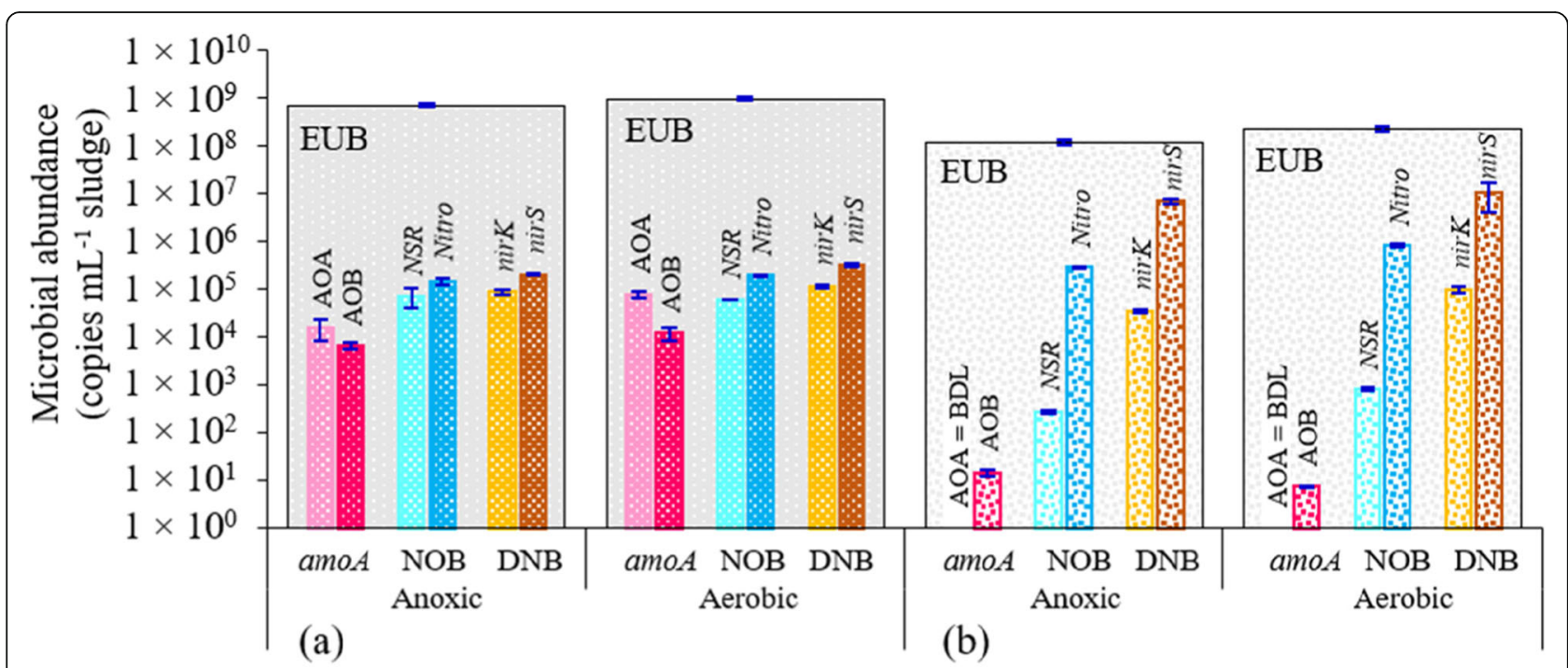

Fig. 3 Microbial abundance of $A O A, A O B, N O B, D N B$ and total bacteria (EUB) a at the SF 1 with low COD:N and $\mathbf{b}$ the SF 2 with high COD:N. Remark: $\mathrm{BDL}=$ below method detection limit 


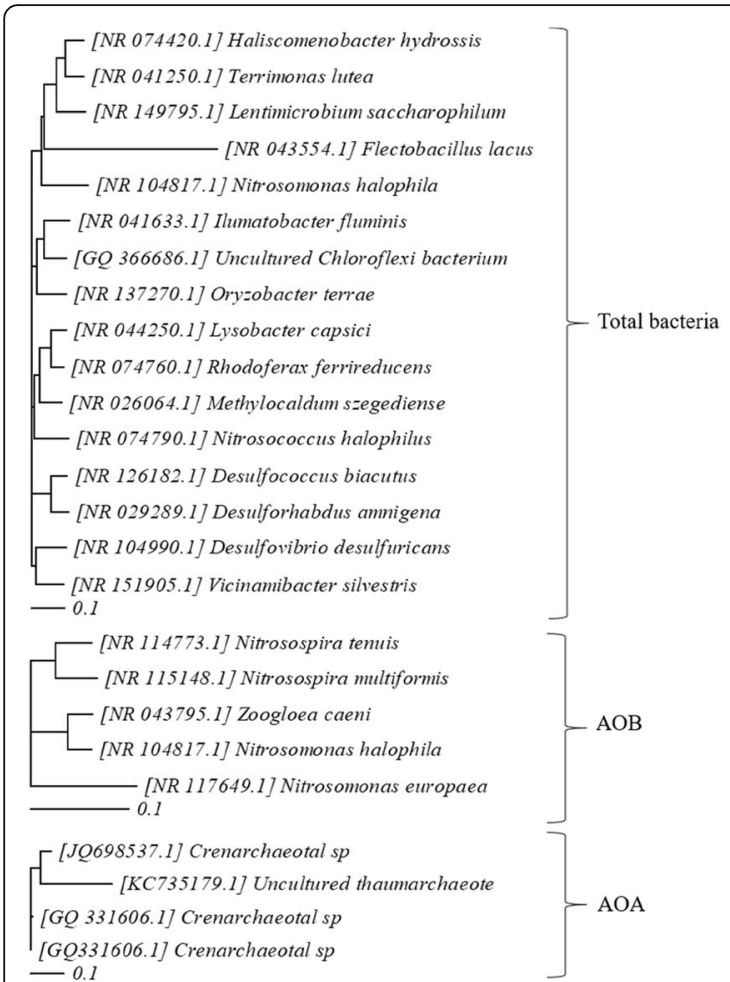

(a)

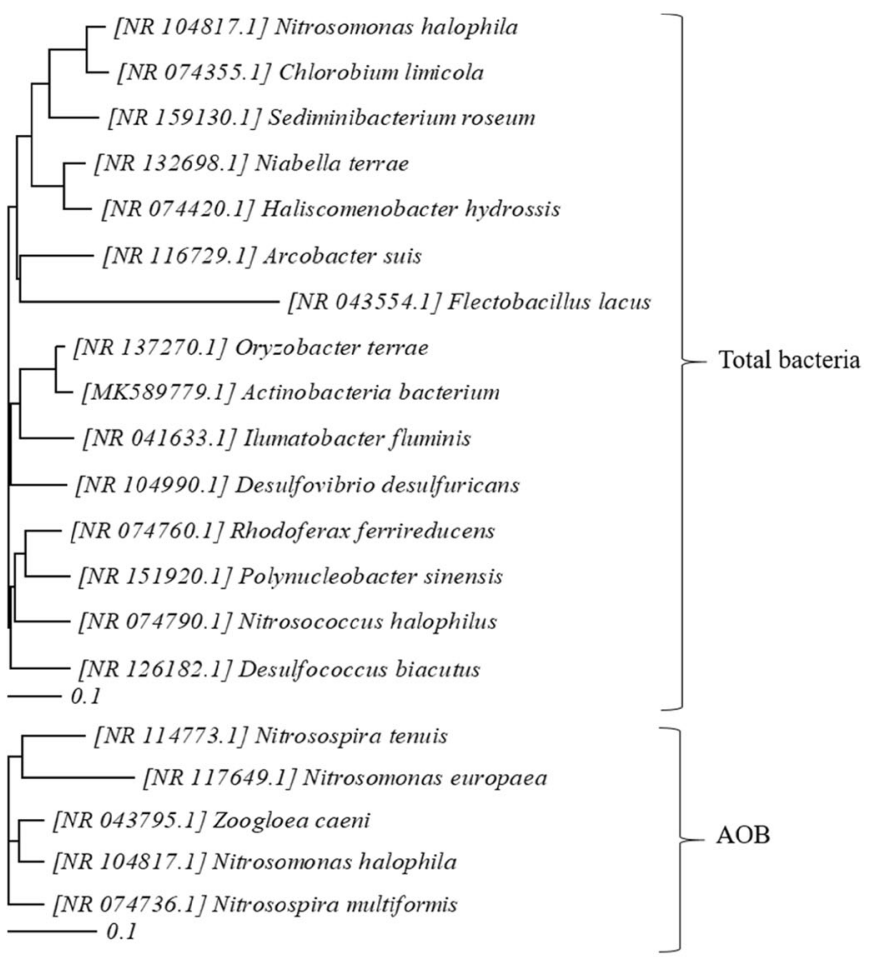

(b)

Fig. 4 Phylogenetic tree of microbial communities at a the SF 1 with low COD:N and $\mathbf{b}$ the $\mathrm{SF}_{2}$ with high COD:N

sp. was the dominant species at SRT $30 \mathrm{~d}$, while the slow-growing Nitrospira was dominant at SRT $90 \mathrm{~d}$. The results from this work coincided with a study by $\mathrm{Yu}$ et al. The amount of Nitrospira that was found in $\mathrm{SF}_{1}$ with long SRT ( $>60 \mathrm{~d}$ ) was significantly higher than the amount of Nitrospira in $\mathrm{SF}_{2}$ with short SRT (7 d). Moreover, Huang et al. [26] studied distribution of NOB communities in the full-scale WWTP by controlling DO concentration. They found that Nitrospira was dominant when low DO $\left(<0.9 \mathrm{mg} \mathrm{L}^{-1}\right)$ concentration was controlled, while Nitrobacter increased when DO concentrations were increased at higher than $0.9 \mathrm{mg} \mathrm{L}^{-1}$. This DO fact could explain why Nitrospira was dominant at $\mathrm{SF}_{1}$ (operated with DO concentrations of $0.2-0.9 \mathrm{mg} \mathrm{L}^{-1}$ ) and Nitrobacter was dominant at $\mathrm{SF}_{2}$ (operated with $\mathrm{DO}$ concentrations of $0.6-1.8 \mathrm{mg} \mathrm{L}^{-1}$. Consequently, low DO conditions and long SRT would be the major operating conditions that contributed to high Nitrospira population in WWTP. It should be noted that in this work other NOB communities were not analyzed because the qPCR technique for analysis of 16S RNA would only reveal Nitrospira and Nitrobacter.

\section{Effects of COD:N ratios on populations of DNB}

The abundance of the denitrifying bacteria in this work is shown in Fig. 3. The denitrifiers are found in both anoxic and aerobic tanks of $\mathrm{SF}_{1}$ and $\mathrm{SF}_{2}$. Two gene types (nirK and nirS) were used to characterize denitrifiers. The nirK-type bacteria in both $\mathrm{SF}_{1}$ and in $\mathrm{SF}_{2}$ were found to be $10^{4}$ copies $\mathrm{mL}^{-1}$ sludge in anoxic tanks and $10^{5}$ copies $\mathrm{mL}^{-1}$ sludge in aerobic tanks. For the nirStype denitrifiers, in $\mathrm{SF}_{1}$ anoxic and aerobic tanks, the bacteria were present in the same order of magnitude $\left(10^{5}\right)$. However, in $\mathrm{SF}_{2}$ the nirS-type denitrifiers existed at two orders of magnitude higher $\left(10^{6}\right.$ in anoxic tank and $10^{7}$ in aerobic tank) than the nirK-type denitrifiers $\left(10^{4}\right.$ in anoxic tank and $10^{5}$ in aerobic tank). The higher population of nirS-type denitrifiers is attributed to the high COD:N ratio $\mathrm{SF}_{2}$. This observation is similar to the results from Wang et al. [27]. They found the number of nirS-type denitrifiers $\left(10^{4}\right.$ to $\left.10^{5}\right)$ was higher than that of nirK-type denitrifiers $\left(10^{3}\right.$ to $\left.10^{4}\right)$ in two full-scale WWTPs (upflow anaerobic sludge blanket and anaerobic/aerobic). Geets et al. [28] reported that nirK-type denitrifiers $\left(10^{5}\right)$ were lower than nirS-type denitrifiers $\left(10^{6}\right)$ in the sludge of industrial influent of anaerobic digester. They also found that nirK-type denitrifiers $\left(10^{6}\right)$ were lower than nirS-type denitrifiers $\left(10^{7}\right)$ in the sludge of domestic wastewater influent from hospital wastewater. From the present work and the cited studies, it is recommended that the nirS-type denitrifier growth be encouraged in full-scale WWTPs. 
The bacterial species of denitrifiers at $\mathrm{SF}_{1}$ are shown to be similar to those at $\mathrm{SF}_{2}$ by PCR-DGGE technique (Fig. 3). The identified denitrifiers belonged to phyla Acidobacteria, Actinobacteria Bacteroidetes, Chloroflexi, Proteobacteria (Table S2). These five main phyla from this study are consistent with the work of Shen et al. [19]. They found these same phyla in full-scale domestic WWTPs (step-feed and anoxic/aerobic process). Wang et al. [27] also investigated the denitrifier communities in full-scale anoxic/oxic reactors using different analytical technique (next generation sequencing (NGS) by pyrosequencing and Illumina highthroughput sequencing). For this reason, Wang et al. [27] were more specific than the results from this work, identifying Genus of Thauera, Paracoccus, Hyphomicrobium, Comamonas and Azoarcus. In further research work, new and/or advanced techniques on the NGS with different variable regions should be recommended in full-scale WWTPs in order to identify specific denitrifier groups. With additional information we should understand which denitrifier communities are most effective in overall biological nitrogen removal in WWTPs.

\section{Conclusions}

In earlier studies it has been shown that TN removal is improved with higher COD:N ratios, longer SRTs, and low DO concentrations in anoxic zones. This work demonstrated that each variable is important in order to achieve adequate treatment in full-scale step-feed WWTPs. SF 1 had longer SRT (>60 d) and low anoxic DO (average $0.2 \mathrm{mg} \mathrm{L}^{-1}$ ), but its low COD:N ratio (4:1) substantially impeded the denitrification portion of treatment. The COD: $\mathrm{N}$ ratio (10:1) at $\mathrm{SF}_{2}$ would provide enough carbon for denitrification, but the average DO $\left(0.6 \mathrm{mg} \mathrm{L}^{-1}\right)$ in the anoxic region was too high for complete TN removal.

The distributions of archaeal and bacterial communities are dependent on operating parameters of the WWTP. At $\mathrm{SF}_{1}$ with low COD:N ratio, low DO, long SRT and high temperature the microbial abundance of $\mathrm{AOA}$ was greater than that of $\mathrm{AOB}$. However, at $\mathrm{SF}_{2}$ with opposite parameter values, the $\mathrm{AOB}$ was more abundant. The predominant $\mathrm{AOB}$ communities were Nitrosomonas sp., Nitrosospira sp., Zoogloea sp. and Nitrosoccus sp. Higher amounts of Nitrospira were present at lower COD:N ratios. Higher amounts of Nitrobacter were found with high DO concentrations and higher COD:N. This work shows that at high COD:N ratio, nirS-type denitrifiers are more prevalent than nirS-type denitrifiers. General microbial communities belonged to phyla Acidobacteria, Actinobacteria Bacteroidetes, Chloroflexi, Proteobacteria were identified.

The results from this work, longer SRT $>30 \mathrm{~d}$ could be suggested as possible practical solution on issue of solving carbon limitation when treating low COD:N wastewater. Another practical solution on issue of reducing aeration energy, DO concentration in aeration tank should be maintained from 0.9 to $1.4 \mathrm{mg} \mathrm{L}^{-1}$.

\section{Supplementary information}

Supplementary information accompanies this paper at https://doi.org/10. 1186/s42834-020-00064-6.

Additional file 1 : Figure S1. DGGE fingerprints of (a) total bacteria, (b) amoA-AOB and (c) Arch amoA-AOA genes. Table S1. Oligonucleotide primers for $\mathrm{PCR}$ amplification via quantitative polymerase chain reaction ( $\mathrm{PPCR}$ ) and denaturing gradient gel electrophoresis (DGGE) techniques. Table S2. $A O A, A O B$ and total bacteria communities.

\section{Acknowledgements}

This work was supported by the Thailand Science Research and Innovation (TSRI), Kasetsart University Research and Development Institute (KURDI) and Faculty of Engineering, Kasetsart University, Bangkok, Thailand (under Postdoctoral fellowship no. Post Doc.62/08/ENV) for grants that supported this research. The authors also would like to thank John Elliott (Golden, Colorado) for great help and Nimaradee Boonapatcharoen at Pilot plant development and training institute to support instrument in molecular analysis.

\section{Authors' contributions}

All authors read and approved the final manuscript.

\section{Funding}

This work was supported by the Thailand Science Research and Innovation (TSRI), Kasetsart University Research and Development Institute (KURDI) and Faculty of Engineering, Kasetsart University, Bangkok, Thailand (under Postdoctoral fellowship no. Post Doc.62/08/ENV).

\section{Availability of data and materials}

The data used to support the findings of this study are available from the corresponding author upon request.

\section{Competing interests}

The authors declare they have no competing interests.

\section{Author details}

${ }^{1}$ Department of Environmental Engineering, Faculty of Engineering, Kasetsart University, Bangkok 10900, Thailand. 'Department of Water Resources and Environmental Engineering, Tamkang University, New Taipei City 25137, Taiwan. ${ }^{3}$ Department of Environmental Engineering, Kyungpook National University, Daegu 41566, Republic of Korea. ${ }^{4}$ Advanced Institute of Water Industry, Kyungpook National University, Daegu 41566, Republic of Korea.

Received: 6 April 2020 Accepted: 10 September 2020

Published online: 01 October 2020

\section{References}

1. Peng YZ, Ge SJ. Enhanced nutrient removal in three types of step feeding process from municipal wastewater. Bioresour Technol. 2011;102:6405-13.

2. Riffat R. Fundamentals of wastewater treatment and engineering. London: CRC Press; 2012

3. Johnson BR, Daigger GT, Crawford G, Wable MV, Goodwin S. Full-scale stepfeed nutrient removal systems: a comparison between theory and reality. The 76th Annual Water Environment Federation Technical Exhibition and Conference. Los Angeles; 2003.

4. Amad O. Step feed BNR process achieving $T N<4 \mathrm{mg} \mathrm{L}^{-1}$ : a case study for WSSC - Piscataway WWTP, Prince George County, Maryland. The 76th Annual Water Environment Federation Technical Exhibition and Conference. Los Angeles; 2003.

5. Tchobanoglous G, Burton FL, Stensel HD. Wastewater engineering: treatment and reuse. 4th Singapore: McGraw-Hill Higher Education; 2004.

6. Wang QB, Chen QW. Simultaneous denitrification and denitrifying phosphorus removal in a full-scale anoxic-oxic process without internal recycle treating low strength wastewater. J Environ Sci-China. 2016;39: 175-83.

7. Ge SJ, Peng YZ, Lu CC, Wang SY. Practical consideration for design and optimization of the step feed process. Front Env Sci Eng. 2013;7:135-42. 
8. Carrera J, Vicent T, Lafuente J. Effect of influent COD/ N ratio on biological nitrogen removal (BNR) from high-strength ammonium industrial wastewater. Process Biochem. 2004;39:2035-41.

9. Chiu YC, Lee LL, Chang CN, Chao AC. Control of carbon and ammonium ratio for simultaneous nitrification and denitrification in a sequencing batch bioreactor. Int Biodeter Biodegr. 2007;59:1-7.

10. Noophan P, Paopuree P, Kanlayaras K, Sirivithayapakorn S, Techkarnjanaruk S. Nitrogen removal efficiency at centralized domestic wastewater treatment plants in Bangkok, Thailand. EnvironmentAsia. 2009;2:30-5.

11. Davies WJ, Le MS, Heath CR. Intensified activated sludge process with submerged membrane microfiltration. Water Sci Technol. 1998;38:421-8.

12. Pochana K, Keller J. Study of factors affecting simultaneous nitrification and denitrification (SND). Water Sci Technol. 1999;39:61-8.

13. Zhao HW, Mavinic DS, Oldham WK, Koch FA. Controlling factors for simultaneous nitrification and denitrification in a two-stage intermittent aeration process treating domestic sewage. Water Res. 1999;33:961-70.

14. Meng QJ, Yang FL, Liu LF, Meng FG. Effects of COD/N ratio and DO concentration on simultaneous nitrification and denitrification in an airlift internal circulation membrane bioreactor. J Environ Sci-China. 2008;20:933-9.

15. Kayee $\mathrm{P}$, Sonthiphand $\mathrm{P}$, Rongsayamanont $\mathrm{C}$, Limpiyakorn T. Archaeal amoA genes outnumber bacterial amoA genes in municipal wastewater treatment plants in Bangkok (Retracted article. See vol. 72, pg. 262, 2016). Microb Ecol. 2011;62:776-88.

16. Gao JF, Luo X, Wu GX, Li T, Peng YZ. Quantitative analyses of the composition and abundance of ammonia-oxidizing archaea and ammoniaoxidizing bacteria in eight full-scale biological wastewater treatment plants. Bioresour Technol. 2013;138:285-96.

17. Limpiyakorn T, Sonthiphand P, Rongsayamanont C, Polprasert C. Abundance of amoA genes of ammonia-oxidizing archaea and bacteria in activated sludge of full-scale wastewater treatment plants. Bioresour Technol. 2011;102:3694-701.

18. Sinthusith N, Terada A, Hahn M, Noophan P, Munakata-Marr J, Figueroa LA. Identification and quantification of bacteria and archaea responsible for ammonia oxidation in different activated sludge of full-scale wastewater treatment plants. J Environ Sci Heal A. 2015;50:169-75.

19. Shen YJ, Yang DH, Wu Y, Zhang H, Zhang XX. Operation mode of a stepfeed anoxic/oxic process with distribution of carbon source from anaerobic zone on nutrient removal and microbial properties. Sci Rep-UK. 2019;9:1153.

20. Leininger S, Urich T, Schloter M, Schwark L, Qi J, Nicol GW, et al. Archaea predominate among ammonia-oxidizing prokaryotes in soils. Nature. 2006:442:806-9.

21. Santoro AE, Francis CA, de Sieyes NR, Boehm AB. Shifts in the relative abundance of ammonia-oxidizing bacteria and archaea across physicochemical gradients in a subterranean estuary. Environ Microbiol. 2008;10:1068-79.

22. Treusch AH, Leininger S, Kletzin A, Schuster SC, Klenk HP, Schleper C. Novel genes for nitrite reductase and Amo-related proteins indicate a role of uncultivated mesophilic Crenarchaeota in nitrogen cycling. Environ Microbiol. 2005; 7:1985-95.

23. Martens-Habbena W, Berube PM, Urakawa H, de la Torre JR, Stahl DA. Ammonia oxidation kinetics determine niche separation of nitrifying archaea and bacteria. Nature. 2009:461:976-9.

24. Chouari R, Guermazi S, Sghir A. Co-occurence of Crenarchaeota, Thermoplasmata and methanogens in anaerobic sludge digesters. World J Microb Biot. 2015;31:805-12.

25. Yu T, Qi R, Li D, Zhang Y, Yang M. Nitrifier characteristics in submerged membrane bioreactors under different sludge retention times. Water Res. 2010;44:2823-30

26. Huang ZH, Gedalanga PB, Asvapathanagul P, Olson BH. Influence of physicochemical and operational parameters on Nitrobacter and Nitrospira communities in an aerobic activated sludge bioreactor. Water Res. 2010;44:4351-8.

27. Wang Z, Zhang XX, Lu X, Liu B, Li Y, Long C, et al. Abundance and diversity of bacterial nitrifiers and denitrifiers and their functional genes in tannery wastewater treatment plants revealed by high-throughput sequencing. PLoS One 2014;9;e113603.

28. Geets J, de Cooman M, Wittebolle L, Heylen K, Vanparys B, De Vos P, et al. Realtime PCR assay for the simultaneous quantification of nitrifying and denitrifying bacteria in activated sludge. Appl Microbiol Biot. 2007;75:211-21.

\section{Publisher's Note}

Springer Nature remains neutral with regard to jurisdictional claims in published maps and institutional affiliations.

Ready to submit your research? Choose BMC and benefit from:

- fast, convenient online submission

- thorough peer review by experienced researchers in your field

- rapid publication on acceptance

- support for research data, including large and complex data types

- gold Open Access which fosters wider collaboration and increased citations

- maximum visibility for your research: over $100 \mathrm{M}$ website views per year

At BMC, research is always in progress.

Learn more biomedcentral.com/submissions 